\title{
MENYEMAI NALAR KEBHINNEKAAN DALAM MEWUJUDKAN PENDIDIKAN MULTIKULTURAL
}

\author{
Mohamad Anas \\ Program Pascasarjana Ilmu Sosial dan Pusat Mata \\ Kuliah PengeUniversitas Brawijaya \\ Email: anas_phil@ub.ac.id
}

\begin{abstract}
: this paper discusses the multiculturalism idea in the philosophy of Bhinneka Tunggal Ika and nationalism, and multicultural education in the Indonesian context. The article used a qualitative approach to Library Research. Library research carried out is to collect multiculturalism opinions of experts, both the great figures of the history of the Indonesian nation and academics who are concerned about the value of multiculturalism. The results obtained are (1) the concept of Indonesian unity in the philosophy of Bhinneka Tunggal Ika and nationalism is called integrative-pluralist, which is constitutionally realized in the articles of the 1945 Constitution, (2) multicultural education in the Indonesian context must not be ahistorical and able to produce graduates who have the skills to live in a multicultural society so that national integration is maintained.
\end{abstract}

Kata kunci: multiculturalism, education, integration.

Abstrak: tulisan ini membahas ide multikulturalisme pada konsep persatuan Indonesia dalam falsafah Bhinneka Tunggal Ika dan nasionalisme, serta pendidikan multikultural dalam konteks ke-Indonesiaan. Metode yang dipakai dalam penulisan artikel ini adalah kualitatif dengan pendekatan studi kepustakaan. Studi kepustakan yang dilakukan adalah mengumpulkan pendapat multikulturalisme. Materi tentang multikulturalisme disarikan dari beberapa pendapat para ahli, baik tokoh besar sejarah bangsa Indonesia, maupun akademisi yang concern terhadap nilai multikulturalisme. Hasil yang diperoleh adalah (1) konsep persatuan Indonesia dalam falsafah Bhinneka Tunggal Ika dan nasionalisme disebut dengan integrative-pluralis yang secara konstitusional direalisasikan dalam pasal-pasal UUD 1945, (2) pendidikan multikultural dalam konteks ke-Indonesiaan harus tidak bersifat ahistoris dan mampu menghasilkan lulusan yang memiliki keterampilan untuk hidup di masyarakat yang multikultural sehingga integrasi bangsa menjadi terjaga.

Kata kunci: Multikultural, pendidikan, integrasi.

\section{PENDAHULUAN}

Beragam etnis, suku, budaya dan agama pada setiap masyarakat sesungguhnya bisa menjadi modal sosial (capital social) yang mendasar dalam membangun sebuah peradaban, namun beragam budaya tersebut malah terkadang bersifat kontraproduktif yang menimbulkan konflik berkepanjangan antar suku, etnis, budaya, bahkan agama. Dalam konteks global, harus diakui bahwa tidak ada satu wilayah, etnis, agama yang bebas sama sekali dari komunikasi dan interaksi dengan etnis, agama, serta antar golongan lainnya, bahkan terjadi semacam "cultural imperialism"-meminjam isilah Edward Said-yang menghantui setiap lapis masyarakat, terutama pada masyarakatmasyarakat yang terpinggirkan. Sehingga muncullah cultur hybrid, budaya gado-gado, yang kehilangan identitas lokalnya.

Seperti lazimnya sebuah gagasan, multikulturalisme juga melahirkan multitafsir. Kalangan akademisi memaknai multikulturalisme sebagai berkembangnya pengetahuan yang berakar pada filsafat pascamodernisme dan kajian budaya. (J. F. Lyotard, 1991). Selain itu, pemahaman 
terhadap realitas multikultural pun membiakkan prinsip paralogisme di atas monologisme, kemajemukan di atas ketunggalan. Dus, isu-isu yang mengemuka dalam wacana multikulturalisme adalah konsep budaya, relasi budaya dan politik, hak-hak minoritas, identitas, pengakuan, perbedaan, hibriditas, toleransi, solidiritas, relasi kekuasaan dan seterusnya. Pada sisi lain, kalangan politisi memahami realitas masyarakat multikultural lebih sederhana, tidak lebih sebagai masyarakat majemuk, dimana secara situasional adalah sarang persoalan politik. Ujungnya, masyarakat majemuk perlu dikelola dengan kebijakan (Darmawan, 2006:5).

Akar kata multikulturalisme adalah kebudayaan. Secara etimologis, multkulturalisme dibentuk dari kata multi (banyak), kultur (budaya), dan isme (aliran/ paham) (H.A.R Tilaar, 2004:25). Secara hakiki, dalam kata tersebut terkandung pengakuan akan martabat manusia yang hidup dalam komunitasnya dengan kebudayannya masing-masing.

Dengan menggunakan pengertian sederhana, multikultural dapat dipahami sebagai keragaman budaya dalam suatu komunitas. Di dalam keragaman terdapat hubungan timbal-balik atau interaksi, konflik, saling menghormati dan menghargai, toleran, integrasi, dan bahkan disintegrasi. Masyarakat multikultur adalah masyarakat yang terdiri atas ragam etnis dan kebudayaan yang beranekaragam. Kehidupan mereka tidak diatur oleh sistem budaya tunggal dan tertutup, atau dalam terminologi postmodern grand narrative, narasi tunggal, melainkan terdiri atas sistem budaya yang beragam dan nilai yang relatif.

Masyarakat multikultur berbeda dengan masyarakat monokultur, sebuah masyarakat asli (archais) atau etnis yang semua anggotanya masyarakatnya berkarakter sama atau homogen, dan bahkan pada masyarakat yang terikat secara paksa atau tak sadar berdasarkan nilai-nilai yang dominan dan kuat dalam struktur masyarakatnya.
Meskipun konsep masyarakat multikultur masih problematik, secara umum masyarakat multikultur dinyatakan sebagai sebuah kumpulan beraneka ragam masyarakat yang memiliki kebudayaan yang eksis satu sama lain di atas suatu wilayah (Choirul Mahfud, 2006:86).

Istilah multikultural diperkenalkan pertama kali tahun 1964 di Winnipeg/ Manitoba Kanada oleh Charles Hobart. Awalnya, istilah ini merujuk pada suatu fenomena migrasi multietnis dan masyarakat dengan lingkup ruang yang besar. Menurut Parekh, multikulturalisme adalah "just as society with several religions or languages is multi religions or multilingual, a society containing several cultures is multicultural". Dalam konteks pembangunan bangsa, istilah multikultural ini telah membentuk suatu ideologi yang disebut multikulturalisme.

Dalam pandangan Parsudi, gagasan multikulturalisme tidak dapat disamakan dengan konsep keanekaragaman secara suku bangsa atau kebudayaan suku bangsa yang menjadi ciri masyarakat majemuk, karena multikulturalisme menekankan "keanekaragaman kebudayaan dalam kesederajatan".

Ulasan mengenai multikulturalisme mau tidak mau akan mengulas berbagai permasalahan yang mendukung wacana dan ideologi ini, yaitu politik dan demokrasi, keadilan dan penegakan hukum, kesempatan kerja dan berusaha, HAM, hak budaya komunitas dan golongan minoritas, prinsipprinsip etika dan moral, dan tingkat serta mutu produktivitas (Parsudi Suparlan, 2002:1-12). Ini semua merupakan konsepkonsep yang relevan dan terus-menurus harus didiskursuskan dalam ruang publik untuk menemukan titik pijak dalam membangun konsep ini. Sehingga diketemukan bangunan epistemik yang menyejarah, dan arah dari semua ini adalah untuk membangun gagasan multikultural dalam kerangka mengangkat derajat manusia dan kemanusiaan yang berbasis kearifan lokal.Ada beberapa makna multikulturalisme: pada tataran ideologi, 
ia merupakan gagasan yang menekankan pada penerimaan terhadap perbedaan etnik, bahasa dan keragaman praktik kultural dalam sebuah masyarakat plural. Pada pembuat kebijakan, ia bertujuan untuk memelihara harmoni antara kelompok etnik, atau agama yang berbeda serta antar mereka dan negara. Dalam bidang pendidikan, multikulturalisme berarti pengakuan terhadap kontribusi semua kelompok kultural dan dengan demikian yang dikembangkan dalam kurikulum adalah yang dikembangkan harus pula mencakup semua materi dari berbagai kultur.

Sebagai ilustrasi untuk menggambarkan keragaman pemakaan multikultural, Parrillo mengkategorisasi sudut pandang multikulturalisme menjadi tiga kelompok. Pertama, The Inclusionist, para inklusionis mengakui adanya kesatuan nasional di atas dasar kesamaan identitas. Namun mereka memberi pengakuan terhadap keragaman kultur dan kontribusi kelompok minoritas pada kebudayaan nasonal lewat kesenian, kesusteraan dan seterusnya. Dalam pengakuan tersebut tetap terkandung penekanan akan perlunya kebudayaan nasional yang merupakan hasil inkorporasi dari semua kolompok kultural yang ada. Kebudayaan nasional bukan dalam pengertian 'dominant culture', melainkan 'common culture'. Masing-masing kelompok kultur tidak berdiri dengan membawa benderanya masingmasing, melainkan semua bersama-sama menegakkan dan mengibarkan satu bendera warna-warni (pelangi) yang mencerminkan latar belakang keragaman kultural yang ada dalam masayarakat tersebut (Darmawan, 2006:171).

Kedua, the integrative pluralists. Pandangan ini mengibaratkan multikulturalisme bagai sebuah orkes simfoni, dimana berbagai instrumen musik yang berbeda masingmasing memainkan bagiannya sendiri-sendiri. Namun secara bersama-sama menghasilkan suatu kolaborasi musik yang indah, bahkan dengan kekontrasannya satu dengan yang lain. Kultur mayoritas akan lebih diperkaya apabila menyertakan berbagai keunggulan kultur minoritas daripada memaksa mereka untuk mengadopsi paham monokultural, yang dalam dalam jangka panjang justru akan melumpuhkan kreativitas dan kemampuan beradaptasi terhadap perubahan dunia yang makin cepat. Visi pandangan ini tidak melihat identitas nasional sebagai sebuah payung besar yang memayungi semua kelompok kultural dibawahnya, tetapi terdiri dari sekumpulan payung yang terkait satu dengan lainnya. Kekuatan dari kerangka nasional tergantung pada keterkaitan antar payung-payung tersebut, atau dengan kata lain pada seberapa konstruktif yang efektif interaksi yang dijalin oleh kelompokkelompok kultural yang berkoeksistensi dalam suatu negara (Darmawan, 2006:172).

Ketiga, The Separatist, Kelompok multikuturalis ini menolak pendekatan integratif dan pendekatan yang membentuk suatu ikatan bersama atau identitas nasional (common culture). Mereka menolak adanya kultur dominan, dan secara eksklusif mengembangkan tradisi, nilai-nilai, sejarah dan perayaan-perayaan kulturnya sendiri. Karena itu kelompok ini mengedepankan pandangan yang disebut "separatis". Mereka tidak ingin berdiri dengan yang lain di bawah satu bendera pelangi seperti dalam kalangan inklusionis. Kelompok multikulturalisseparatis ini menjalankan apa yang disebut dengan pemujaan terhadap etnis. Kelompok separatis hanya ingin menonjolkan satu jenis mawar dari sekian ragam mawar yang ada. Taman bunga hanya diisi oleh satu jenis mawar yang dianggap paling unggul varietasnya. Sedangkan kelompok inklusionis, mencoba mencari kesamaan dasar yang dimiliki oleh semua jenis mawar itu. Taman memang dihiasi berbagai jenis mawar, tetapi tetap ada satu mawar yang menjadi primadona yang merupakan hasil persilangan/hibridasi dari semua jenis mawar tersebut. Sementara kelompok integratif pluralis melihat semua warna dan varietas mawar itu sama indah. Jadi, dengan membiarkan serubu jenis mawar mawar mendekorasi sebuah taman berarti 
menampilkan seribu keindahan, sehingga taman akan jauh lebih indah (Darmawan, 2006:172-173).

Wacana-wacana tentang multikulturalisme tidak pernah luput dari kritik. Beberapa kritik terhadap multikulturalisme tidak hanya datang dari kubu yang anti atau menolak multikulturalisme, tetapi kritik juga datang dari kubu yang pro terhadap multikulturalisme. Mereka yang menolak pada umumnya barasal dari kelompok mayoritas/kultur dominan, kubu konservatif dan kelompok asimilasionis. Sedangkan kritik dari arah yang pro berasal dari kalangan critical multiculturalist feminis dan kelompok kiri.

Pertama, kritik yang datang dari yang anti multikulturalisme pada dasarnya disebabkan proyek membangun-negara. Multikulturalisme diyakini mempunyai prinsip-prinsip yang dapat menjadi halangan bagi kelangsungan proyek itu, yakni yang dapat menimbulkan ketegangan konflik antara identitas nasional (nasionalisme) dan identitas kelompok kultural yang sangat beragam. Gerakan multikulturalisme seringkali dituduh menolak keberadaan 'common culture', dan lebih mempromosikan identitas dan pengelompokan berdasarkan ras, etnis, dan sub-kultur. Dan pada titik ektrim, multikulturalisme dituduh mendorong munculnya separatisme dan mengancam integrasi sosial dan persatuan bangsa (Darmawan, 2006:173).

Kedua, kubu pro multikulturalisme. Kelompok kiri (the left) di Amerika misalnya, mengkritik kebudayaan multikulturalisme telah melakukan depolitisasi terhadap multikulturalisme dengan penekanannya yang berlebihan pada perayaan atas keragaman kultural yang bersifat kosmetik belaka. Mereka tidak melihat gerakan multikulturalisme selama ini sebagai perjuangan yang bersifat transformatif dalam melawan rasisme dan "Kulit Putih". Di mata kaum kiri, multikukturalisme tidak mempunyai strategi untuk menghapuskan penindasan rasial/etnik, dan hanya merupakan perlawanan terhadap kultur dominan. Multikulturalisme hanya gerakan di permukaan, tidak menyentuh akar persoalan (Darmawan, 2006:174). Ini terjadi karena multikulturalisme terlalu memberi penakanan pada perbedaan kultural dari kelompok-kelompok etnik minoritas daripada mengedepankan apa yang dapat menyatukan semua kelompok yang samasama diperlakukan tidak adil, mengalami diskriminasi, subordinasi dan ekploitasi ekonomi.

Sementara, ketiga, bagi kalangan feminis, multikulturalisme dikritik kerena dianggap gagal membela kepentingan perempuan. Banyak hak perempuan diabaikan dan dilanggar justru atas nama multikulturalisme. Kondisi ini jelas terlihat di negara-negara Barat yang membiarkan kelompok kultur minoritas menerapkan tradisi mereka yang melanggar hak asasi manusia, seperti pembatasan pendidikan, "kawin paksa", bahkan penyunatan kaum perempuan.

Kelemahan lain dari multikulturalisme adalah pada persepsi multikulturalis yang menganggap kultur itu inheren pada kelompok etnik, serta kultur dianggap sebagai realita yang bersifat pasti dan statis. Kultur Afrika misalnya, melekat pada orang Afrika dan selamanya begitu tanpa ada perubahan dan tidak terbuka ruang kemungkinan melahirkan kultur baru yang bisa jadi berbeda dengan generasi sebelumnya, atau membuka kemungkinan terjadi hibridasi antar kultur. Dengan demikian kultur bersifat deterministik dan ahistoris.

Kemudian ada problem kesederajatan dan ketiadaan 'ukuran bersama'. Jika prinsip kesedarajatan diterima kebenarannya, maka menjadi tidak benar pula anggapan bahwa kultur feodal (misalnya) merupakan kultur yang lebih buruk daripada kultur demokrasi. Kalau begitu, Feodalisme tidak perlu dibuang, karena ada juga kelompok yang tidak menganggapnya sebagai persoalan. Namun, bukankah hal yang tidak mungkin meminta orang untuk menerima kultur feodalisme (yang tidak mengakui kesederajatan antar manusia) sebagai kultur yang sama baiknya dengan kultur demokrasi (yang menjunjung 
kesamaan)? Problem lain adalah argumen multikulturalisme yang mengatakan bahwa nilai-nilai kultural tidak dapat dinilai atau diukur dengan standar yang sama. Apa yang baik bagi kita, belum tentu baik bagi mereka. Multikulturalisme tidak ingin menilai kultur mereka, yang ditekankan hanya pengakuan, itu saja! Persoalan yang akan muncul adalah jika nilai-nilai atau praktik-praktik kultur lain itu bertentangan atau bahkan dianggap haram dengan dalam kulturnya sendiri. Misalnya, apakah orang harus membiarkan (toleran) pemerkosaan terhadap perempuan berlangsung terus hanya karena itu praktik kultur yang dibenarkan dalam kultur tententu. Dengan demikian, yang terjadi sebetulnya bukan sikap saling menghormati, tetapi sikap 'masa bodoh' tidak peduli dengan nasib orang lain.

Kalangan multikulturalis menyangggah akan adanya relativisme kultur dan etis karena dipandang hanya menonjolkan perbedaan semata. Menurut kaum multikulturalis, diperlukan dialog terus-menerus ketika terjadi benturan nilai kultural. Tidak jelas apa yang diusulkan oleh kaum multikultural, sementara para pengkritiknya pun malah mengarahkan problem etika ke arah pada persolan ekonomi dan politik.

Menurut saya, diperlukan etika diskursus untuk menyelesaikan persoalan ini. Sebuah 'perbincangan' etika yang diikuti oleh semua komunitas, baik etnik maupun agama. Wacana multikulturalisme, apalagi dalam konteks Indonesia, bukanlah suatu gagasan yang telah jadi. Diperlukan sumbangan kritik dari berbagai rumpun keilmuan lain, bisa jadi dari filsafat (terutama teori postkolonial) untuk mematangkan gagasan

Keragaman budaya sesungguhnya mempunyai karakter yang bersifat ganda, di satu sisi keragaman merupakan potensi besar untuk membangun peradaban besar, tetapi di sisi lain juga menjadi ancaman tersendiri, yakni berupa konflik jika tidak mampu dikelolah dengan arif dan bijak, maka primordialisme tidak mampu dibendung yang mengakibatkan perang antar budaya, etnis, dan bahkan agama. Jika konflik horizontal dalam masyarakat multikultural tidak terjadi berarti telah terbangun toleransi yang tinggi yang dianut oleh masyarakat. Dalam konteks lokal, ada asumsi yang berkembang, hal itu disebabkan adanya ikatan adat yang begitu kuat, sehingga konflik horisontal bisa diantisipasi sedini mungkin

Di Indonesia, fenomena divergendisintegratif nampak setelah runtuhnya rezim Orde Baru, bersamaan dengan makin masifnya praktik-praktik kapitalisme neoliberal, salah satu ciri terkuat dari globalisasi. Fenomena divergen-disintegratif di Indonesia berjalan seiring dengan semua itu, dipicu oleh proses desentralisasi dan otonomi daerah yang dikukuhkan melalui Undang-Undang (UU) Nomor 22 Tahun 1999 mengenai Pemerintahan Daerah dan UU No 15/1999 mengenai Perimbangan Keuangan Pusat dan Daerah.

Alih-alih untuk mempersatukan "mempersamakan" (conformity) semua elemen negeri ini (slogan Orde Baru), atau mensejahterakan masyarakat dengan kebijakan disentralisasi dan otonomi daerah (Orde Reformasi), akan tetapi justru penghargaan dan pengakuan atas kehadiran 'yang lain' (the other) terabaikan. Politik sentralisme kekuasaan yang pada masa Orde Baru memaksakan paradigma "monokulturalisme" dengan mengatastanamkan persatuan dan kesatuan. Politik sentralistik atau paradigma monokultral ini telah menghancurkan local cultural geniuses, seperti tradisi "pela gandong" di Ambon, "republik nagari" di Sumatera Barat. Akibatnya, paradigma tunggal ini mengalami anomali dan muncullah reaksi-reaksi balik, yang mengandung implikasi-implikasi negatif bagi rekonstruksi kebudayaan Indonesia yang multikultural. Sementara proses otonomisasi dan desentralisasi kekuasaan pemerintahan kini justru mengakibatkan terjadinya peningkatan gejala "provinsialisme", "etnisitas", dan kesukuan.

Fenomena divergen-disintegratif ini kian nyata dalam keseharian hidup 
bermasyarakat dan berbangsa, berupa rasa kedaerahan, identitas kesukuan, kelompok, dan agama yang menguat, menimbulkan fragmentaris kelompok dan konflik-konflik horizontal yang sebelumnya tidak muncul ke permukaan. Hal ini dapat dilihat dari kasus-kasus Poso, Kupang, Mataram, Sampit, Mamasa, Ambon, Aceh, dan sebagainya. Ancaman nyata kehidupan bangsa yang pluralis harus betul-betul diperhatikan. Toleransi, inklusivisme, dan penolakan terhadap berbagai jenis fundamentalisme dapat dipupuk kalau ada pengakuan terhadap multikulturalisme, yang diyakini sebagai pendukung pluralisme, yaitu keberadaan budaya yang sama tinggi dan sama bernilai di dalam suatu masyarakat yang pluralis.

Sesuai dengan problem tersebut, tulisan ini menganalisis dan memahami lebih jauh Persatuan Indonesia atau konsep kebangsaan, dapat dimulai dengan memahami 1) konsep Persatuan Indonesia itu, 2) keberagaman manusia Indonesia namun dapat bersatu, dan 3) konsep persatuan, bhinneka tunggal $i k a$, nasionalisme, dan sekaligus negara.

\section{METODE}

Metode penulisan pada artikel ini adalah kualitatif, yaitu studi kepustakaan tentang multikulturalisme. Materi tentang multikulturalisme disarikan dari beberapa pendapat para ahli, baik tokoh besar sejarah bangsa Indonesia, maupun akademisi yang concern terhadap nilai multikulturalisme. Kemudian, wacana tentang multikulturalisme dinterpretasikan sesuai dengan konteks keIndonesiaan terkini, dan hasil interpretasi tersebut dipakai untuk menganalisis problem sosial dan pendidikan khususnya kurikulum pendidikan multikultural yang semestinya diajarkan bagi masyarakat Indonesia.

\section{HASIL DAN PEMBAHASAN}

\section{Konsep Persatuan Indonesia dalam Falsafah Bhinneka Tunggal Ika dan Nasionalisme}

Soekarno dalam pidato 1 Juni 1945 menyatakan, "kita hendak mendirikan suatu negara "semua untuk semua", karena itu jikalau tuan-tuan terima baik, marilah kita mengambil sebagai dasar negar yang pertama: Kebangsaan Indonsia. Kebangsaan Indonesia yang bulat! Bukan kebangsaan Sumatera, bukan kebangsaan Borneo, Sulawesi, Jawa atau lain, tetapi kebangsaan Indonesia yang bersama-sama menjadi dasar satu nationale staat". Pidato itu adalah bukti jalan panjang menuju Indonesia bersatu, satu dalam arti mempunyai ciri khas, sifat dan karakter yang utuh tidak terbagi-bagi puncaknya dapat ditelisik dari peristiwa manifestasi 'sumpah pemuda' yang dipelopori kaum muda pada tanggal 28 Oktober 1928. Manifesto 'Satu Nusa, Satu Bangsa dan Satu Bahasa' ini menjadi tonggak persatuan Indonesia. Mereka meleburkan diri dalam persatuan dengan mengabaikan ego-ego sektoral-sempit, kesukuan, etnis, dan lainlain untuk mencapai cita-cita besar, yakni kemerdekaan.

Pada pembukaan UUD 1945 yang termuat dalam Berita Republik Indonesia tahun ke II, No.7, bahwa mendirikan negara Indonesia, digunakan aliran pemikiran 'negara kesatuan' yaitu Negara mengatasi segala paham golongan dan paham perseorangan, jadi bukan negara berdasarkan individualisme, dan juga bukan negara class staat (Negara Klassa) yang mengutamakan satu golongan. Maka Negara Indonesia adalah negara yang berdasarkan asas kekeluargaan, tolong menolong, atau dengan dasar keadilan sosial. Sehingga dapat dipahami tujuan pendirian Negara Indonesia adalah kesejahteraan umum (Kaelan, 2009:184). Paham Integralistik yang diusulkan oleh Prof. Soepomo menyebutkan bahwa negara adalah satu kesatuan organik (Hegel, Adam Muller dan Spinoza). Paham ini menempatkan masyarakat lebih diutamakan daripada individu, individu lebur dalam jejaring sosial tanpa mempunyai kekuatan untuk mengemukakan pendapat. Paham ini memang bertentangan dengan gagasan negara menurut kelompok Liberalisme yang menekankan hak individu dalam Negara.

Paham Integralistik yang diusulkan 
oleh Soepomo lalu disempurnakan oleh Mohamad Hatta sebagai berikut. Menurut Hatta, negara, dalam paham integralistik Eropa, menumbuhkan negara kekuasaan, karena itu perlu dilengkapi kemerdekaan berserikat, berkumpul dan menyatakan pendapat. Maka, integralistik Indonesia adalah kemakmuran masyarakat diutamakan, namun harkat dan martabat manusia tetap dihargai.

Integralistik Indonesia tidak memahami negara yang berdiri terpisah dengan individuindividu, sebagaimana paham dualistis integralistik Jerman. Tidak pula mempunyai kepentingan sendiri (kepentingan pemerintah) yang terlepas atau bahkan bertentangan dengan kepentingan rakyatnya. Dengan kata lain, kebijakan pemerintah itu berdasarkan untuk mencapai kemaslahatan rakyat (tashorruf al-imam 'ala ar-ra'iyyah manutun bi almaslahah).

Secara konstitusional, bentuk realisasi Persatuan Indonesia tercantum dalam UUD 1945, yakni pasal 26 tentang warga negara, pasal 31-32 tentang pendidikan dan kebudayaan nasional Indonesia, pasal 35-36 tentang Bendera Negara Indonesia, Bahasa Negara Indonesia, Lambang Negara dan Lagu Kebangsaan. Pada tanggal 20 April 1932, Hatta menyebut bahwa tidak ada kemerdekaan tanpa persatuan. beliau mengatakan bawha: ".... dengan persatuan kita maksud persatuan bangsa, satu bangsa yang tidak dapat dibagi-bagi...di dalam pangkalan bangsa yang satu itu boleh terdapat berbagai paham politik...dan kalua dating marabahaya yang menimpa pergerakan di sanalah kita tempat menunjukkan persatuan hati, di sanalah kita harus berdiri sebaris... kita menyusun 'persatuan'...kita menolak "persatean" (Daulat Rakyat, 1932).

Bangsa ini mempunyai lebih dari 750 suku bangsa. Semua suku bangsa yang tersebar luas di bumi Nusantara ini sebagai pemangkunya, lalu secara yuridis tanggal 17 Agustus 1945 disatukan dalam satu "persatuan" menjadi bangsa Indonesia. Persatuan bangsa ini hanya akan menjadi 'persatean' jika tidak secara terus menerus ditumbuhkan satu "ruh", jiwa yang sama dalam dimensi Gemeinschaft. Tafsir perihal persatuan tersebut banyak dipengaruhi oleh Ernest Renan dan Otto Bauer dalam mendifinisikan suatu bangsa. Renan menyebut suatu bangsa sebagai satu gerombolan manusia yang mau bersatu, yang merasa dirinya bersatu. Sementara Otto Bauer, bangsa adalah persamaan perangai yang timbul karena persamaan nasib. Kedua definisi tersebut dianggap telah usang oleh Soekarno, bahkan dianggap belum mengenal adanya ilmu Geopolitik. Berangkat dari tersebut, Soekarno memaksudkan persatuan bukan hanya dari sisi jiwa, ruh, watak atau karakternya, akan tetapi juga harus mempertimbangkan tampat atau bumi yang dipijaknya. Jadi, persatuan yang dimaksud tersebut adalah "persatuan antara manusia dengan tempat tinggalnya (Soekarno, 1 Juni 1945).

Semboyan dan Istilah-istilah seperti Bhinneka Tunggal Ika, Nusantara, Pancasila sudah ada pada era Majapahit. Tiga istilah ini konon telah terdapat dan termuat dalam Kakawin Nagarakertagama karangan Empu Prapanca dan buku Sutasoma karangan Empu Tantular, meski dengan pengertian dan pemaknaan sedikit berbeda. Sebagai contoh, dalam buku tersebut istilah Pancasila di samping mempunyai arti "berbatu sendi yang lima" (dalam bahasa Sansekerta), juga mempunyai arti "pelaksanaan kesusilaan yang lima" (Pancasila Krama), yaitu: Tidak boleh melakukan kekerasan; Tidak boleh mencuri; Tidak boleh berjiwa dengki; Tidak boleh berbohong; Tidak boleh mabuk minuman keras (Darmodihardjo, 1978:6).

Karakteristik menonjol dari nalar Indonesia adalah kebhinekaan. Semboyan Bhinneka Tunggal Ika sebenarnya juga telah ada di kitab Negara Kartagama yang berbunyi Bhinneka Tunggal Ika Tan Hana Dharma Mangrua yang berarti "meskipun agama-agama itu kelihatan berbeda bentuk namun pada hakekatnya satu jua" (Fauzi, 1983:17). Dari zaman Majapahit ini telah 
bisa diambil nilai-nilai seperti persatuan dalam keberbedaan. Dengan wilayah yang sangat luas, yakni seluruh wilayah nusantara, Majapahit telah memberi ilham persatuan nusantara menjadi persatuan Indonesia. Ia juga telah memberi contoh bagaimana Indonesia mengusahakan keadilan sosial bagi masyarakat, yakni menuju keadaan negara berdaulat, bersatu dan berwilayah Nusantara, mencapai kehidupan yang "gemah ripah loh jinawi, tata tentrem, kerta raharja" (Darmodihardjo dkk, 1991:21). Dengan kata lain, nilai Persatuan bukan sebuah cerita rakyat yang bersifat utopis melainkan sebuah realitas nyata dalam sejarah perjuangan Bangsa Indonesia (Hanafi, 2018).

Dasar falsafah kebhinekaan ini berangkat dari realitas ke-Indonesiaan yang memang plural, kebhinekaan selalu mempunyai dua sisi yang harus dipahami. Satu sisi jika dikelola dengan bijaksana, maka akan melahirkan sintesa peradaban tinggi sebab meletakkan bagian-bagian yang berbeda itu mempunyai potensi masing-masing untuk disatukan. Meletakkan peran masingmasing dalam harmoni keberagaman, seperti sebuah orkesta musik yang dengan peran masing-masing dari alat-alat musik tersebut. Dalam konteks teori multikultural, model demikian disebut sebagai integrativepluralis. Visi pandangan ini tidak melihat identitas nasional sebagai sebuah payung besar yang memayungi semua kelompok kultural dibawahnya, tetapi terdiri dari sekumpulan payung yang terkait satu dengan lainnya. Kekuatan dari kerangka nasional tergantung pada keterkaitan antar payung-payung tersebut, atau dengan kata lain pada seberapa konstruktif yang efektif interaksi yang dijalin oleh kelompokkelompok kultural yang berkoeksistensi dalam suatu negara.

Analogi sederhana, Soediman K. (1986:16-17) melihat falsafah kekeluargaan sebagai basis untuk mengelola perbedaan. Dalam ikatan sebuah keluarga, ayah, ibu, anak mempunyai peran dan posisi masing- masing yang berbeda, tetapi mereka diikat (disatukan) oleh ikatan darah, keluarga. Inilah yang kemudian disebut dengan semboyan, "perbedaan dalam kesatuan". Sementara semboyan "persatuan dalam perbedaan", diartikan bahwa meskipun dalam keluarga disatukan oleh hubungan darah, akan tetapi keluarga mengakui akan kepribadian setiap individu yang berbeda-beda.

Penyatuan Indonesia atau integrasi nasional (nasionalisme) lalu muncul sebagai akibat kekuasaan fisik imperialis, kesamaan nasib, kesatuan budaya, kesatuan wilayah dan kesatuan asas kerokhanian. Beberapa faktor pembentuk nasionalisme ini sebagaimana yang ditulis oleh Hans Kohn, menurutnya nasionalisme mempunyai unsur: kesatuan asas kerokhanian; kesatuan solidaritas yang besar; kesatuan dalam proses sejarah; bangsa bukan merupakan suatu kesatuan yang abadi (Kaelan, 2009:186). Berdasarkan realitas tersebut, maka nasionalisme Indonesia yang dibangun melalui sejarah panjang dapat diwujudkan dengan menjaga nama baik bangsa, berjiwa dan berkepribadian Pancasila, bangga terhadap kebhinnekaan masyarakat Indonesia, serta setia dan taat kepada norma yang berlaku (Ikhsan, 2017).

\section{Pendidikan Multikultural dalam Konteks Ke-Indonesiaan}

Wacana multikulturalisme dalam Indonesia menemukan momentumnya ketika sistem nasional yang otoritermiliteristik tumbang seiring dengan jatuhnya rezim Soeharto. Saat itu, keadaan negara menjadi chaos dengan berbagai konflik antarsuku bangsa dan antar golongan, yang menimbulkan keterkejutan dan kengerian para anggota masyarakat. Kondisi yang demikian membuat berbagai pihak semakin mempertanyakan kembali sistem nasional seperti apa yang cocok bagi Indonesia yang sedang berubah, serta sistem apa yang bisa membuat masyarakat Indonesia bisa hidup damai dengan meminimalisir potensi konflik.

Untuk mengatasi berbagai konflik horizontal, pendidikan bisa berperan membentuk pandangan siswa mengenai 
kehidupan dan meningkatkan penghargaan terhadap keberagaman. Paradigma multikultural secara implisit juga menjadi salah satu concern dari Pasal 4 Undang-Undang N0. 20 Tahun 2003 Sistem Pendidikan Nasional. Dalam pasal itu dijelaskan, bahwa pendidikan diselenggarakan secara demokratis, tidak diskriminatif dengan menjunjung tinggi HAM, nilai keagamaan, nilai kultural dan kemajemukan bangsa.

Menurut Lie (2007:27), pendidikan multikultural di Indonesia menghadapi tiga tantangan mendasar. Pertama, fenomena homogenisasi terjadi dalam dunia pendidikan akibat tarik ulur antara keunggulan dan keterjangkauan. Para siswa terisolasi dalam sekolah-sekolah sesuai latar belakang sosioekonomi, agama, dan etnisitas. Apalagi pasal yang mengatur pendidikan agama dalam Undang-Undang No 20/2003 membuat sekolah berafiliasi agama merasa enggan menerima siswa tidak seagama. Lalu, terjadi pengelompokan anak berdasar agama, kelas sosio-ekonomi, ras, dan suku. Tiap hari anak-anak bergaul dan berinteraksi hanya dengan teman segolongan. Jika interaksi di luar sekolah juga demikian, pengalaman anak-anak untuk memahami dan menghargai perbedaan menjadi amat langka.

Selama ini arah dan fokus sekolah atau pendidikan hanya diarahkan pada situasi psikologi peserta didik atau pengajar, sarana pendidikan dan kurikulum; hubungan antara tujuan pendidikan dan pilihan sarana pedagogis proses belajar mengajar. Masalahmasalah tersebut mengandaikan semua peserta didik mempunyai kesempatan sama. Keberhasilan pendidikan hanya mengacu ke dua kriteria, yakni proses belajar-mengajar dan hasilnya yang akan diukur dari kompetensi. Sementara latar belakang sosial peserta didik sama sekali tidak dipertimbangkan. Sekolah diandalkan sebagai tempat efektif untuk menaiki jenjang sosial. Melalui sekolah orang berharap akan memperbaiki kehidupannya baik secara ekonomi, budaya maupun posisi dalam hierarki sosial. Imajinasi masyarakat
Prancis mengembangkan gambaran mobilitas sosial dan tiga generasi: kakek petani, orangtua guru, anak menjadi intelektual (penulis), pemimpin perusahaan atau pejabat (Haryatmoko, 2008:12-13).

Di benak masyarakat, sekolah seakan membuka kesempatan sama bagi semua lapisan. Padahal budaya sekolah menuntut suatu syarat tertentu bila ingin mendapatkan tempat terhormat di universitas-universitas ternama. Praktik pedagogis sehari-hari pada pengajar di semua jenjang pendidikan biasanya tidak memperhitungkan latar belakang sosial peserta didik. Ada perilaku keluarga peserta didik kelas bawah yang menghambat kesiapan untuk masuk ke budaya sekolah, terutama yang terkait dengan keterampilan bahasa (Haryatmoko, 2008:15). Budaya kelas sosial yang lebih siap menghadapi persaingan di sekolah ialah budaya kelas atas. Di keluarga-keluarga kelompok sosial ini sudah ada kebiasaan membaca; mereka mempunyai kamus atau ensiklopedi, ada ruang dan waktu belajar, sudah mempunyai komputer; ada kebiasaan berdiskusi sehingga terampil di dalam rekayasa bahasa. Dalam realitas, kelas atas sudah terlebih dahulu memesan tempat-tempat terbaik karena kesiapan mereka bersaing.

Sementara peserta didik kelas bawah harus berjuang keras meniti tangga sekolah karena jauh dari fasilitas pendidikan budaya, tentu saja berbeda dengan mereka yang sejak kecil sudah tidak asing dengan buku, komputer, atau bahkan menulis dan berbicara menjadi bagian dari hidup. Terbiasa dengan lingkungan demikian yang menggunakan bahasa cerdik pandai, maka di sini muncullah ideologi bakat, seakan-akan kemampuan dan keunggulan peserta didik adalah bakat bawaan. Padahal, keberhasilan itu berkat kebiasaan dan telah menjadi kesadaran praktis, kemudian diungkapkan dalam kemampuan dan kelihatannya ilmiah, bisa berkembang lantaran lingkungan sosial tertentu (habitus, menurut P. Bourdie: Le sens pratique, 1980). Ideologi bakat telah menutupi realitas ketidakadilan, yaitu 
bahwa latar belakang sosial menentukan keberhasilan atau kegagalan peserta didik di sekolah. Sistem pendidikan hanya mengakui masa lalu peserta didik yang paling dekat, yaitu jenjang sekolah sebelumnya. Dengan demikian, latar belakang sosial keluarga sama sekali tidak masuk ke dalam perhitungan model komunikasi pedagogi. Akibatnya, pendidik hanya akan menyalahkan masa lalu paling dekat, kemampuan, bakat atau pribadi peserta didik (Haryatmoko, 2008).

Tujuan pendidikan yang diterapkan meskipun nampak bersifat egaliter, seperti: perolehan pengetahuan dan keterampilan atau menjawab permintaan pasar, orientasi humanistik, dan menjawab tantangan sosial, ekonomi, dan masalah keadilan atau bahkan bertujuan untuk kemajuan ilmu iti sendiri. Namun, ini semua seakan mempunyai pra-pengandaian bahwa semua peserta didik berhak memperoleh kesempatan yang sama, akan tetapi kenyataan kelas elite mempunyai kapital budaya dan lebih siap bersaing untuk mendapatkan terbaik di perguruan tinggi. Persoalan ini lebih kompleks ketika pemerintah mengurangi subsidi beberapa perguruan tinggi negeri yang nyata-nayata membahayakan cita-cita pendidikan untuk rakyat.

Tidak mengherankan lagi jika bagi kaum elite, pendidikan merupakan kelanjutan, kelangsungan pewarisan budaya dan bagian dari strategi kekuasaan, sedangkan untuk kelas miskin sekolah merupakan simbolisasi akses ke kalangan elite. Sekolah menjadi satu-satunya yang mampu menjanjikan harapan keberhasilan sosial, sedangkan untuk kalangan atas sistem pendidikan menjamin pelanggengan privilese mereka.

Jika saja sekolah menjadi alar penyeleksi status sosial dan bukan sebagai pendidikan yang membebaskan, maka jelas hal ini mengabaikan dimensi filsafat pendidikan. Pendidikan yang hanya menampakkan wujud instrumentalis dan pragmatis, bahkan menjadi legitimasi negara dan mereproduksi kelas penguasa baru, yang semuanya ujungujungnya mengarah pada polarirasasi kelas sosial dalam masyarakat. Pendidikan yang justru membelenggu kemanusiaannya dalam sistem sekolah yang dikemas ideologi ataau bahkan pencitraan yang ingin mewujudkan manusia yang utuh.

Selera kelas penguasa menentukan budaya, sistem komunikasi dan integrasi kelompok yang dilanggenggkan dalam institusi sekolah. Maka menjadi kepentingan kelompok itu untuk tetap memelihara mitos bahwa sekolah membuka kesempatan bagi semua orang. Mitos ini menghidupkan hasrat mimetis untuk berhasil dalam diri peserta didik yang berasal dari lingkungan miskin. Kebijakan pemerintah mengurangi subsidi perguruan tinggi negeri melalui Undang-Undang BHP, membahayakan citacita pendidikan untuk rakyat. Jalur khusus seleksi mahasiwa baru sudah merupakan diskriminasi terjadap calon mahasiswa dari kalangan miskin.

Tantangan kedua dalam pendidikan multikultural adalah kurikulum. Penelitian Anita Lie (2007:27) atas kurikulum 1994 menganalisis isi 823 teks bacaan dalam 44 buku ajar bahasa Inggris yang digunakan di SMA berdasar jender, status sosioekonomi, kultur lokal, dan geografi. Dalam keempat kategori itu, buku-buku ini masih menunjukkan ketidakseimbangan dan bias yang amat membatasi kesadaran multikultural peserta didik.

Ungkapan You are what you read (Anda dibentuk oleh apa yang Anda baca) perlu melandasi penyusun kurikulum. Jika siswa atau mahasiswa disodori bahan-bahan pelajaran yang mengandung bias (kelas, jender, etnis, agama, suku), siswa akan tumbuh menjadi manusia dengan praduga dan prasangka negatif terhadap orang lain yang berbeda. Keberagaman dan kekayaan budaya Nusantara diakomodasi dalam kurikulum hanya sebatas ikon dan simbol budaya seperti pakaian, kesenian daerah, dan stereotip suku. Tantangan terakhir dan terpenting adalah guru. Kelayakan dan kompetensi guru di Indonesia umumnya masih di bawah standar apalagi untuk 
mengelola pembelajaran multikulturalisme (Lie, 2007).

Tilaar mengupas model pendidikan multikultural di beberapa negara. Tidak ada satu model pendidikan multikultural yang paling cocok untuk suatu bangsa atau komunitas. Model pendidikan multikultural di Indonesia harus berdasar Pancasila yang telah disepakati para pendiri bangsa sebagai jaminan NKRI. Pendidikan multikultural bertujuan mengembangkan manusia Indonesia yang cerdas. Manusia cerdas tidak hanya cerdik dan berkemampuan untuk menguasai ilmu pengetahuan dan menyelesaikan masalah, tetapi juga bermoral, bersikap demokratis, dan empati terhadap orang lain. Manusia cerdas menghargai diri sendiri dan orang lain dari berbagai latar belakang berbeda.

Model pendidikan multikultural mencakup kurikulum yang resmi serta the hidden curriculum (kurikulum tak tertulis dan terencana tetapi proses internalisasi nilai, pengetahuan, dan keterampilan justru terjadi di kalangan peserta didik). Dalam kurikulum resmi, pendidikan multikultural sebaiknya diintegrasikan ke semua mata pelajaran dan kegiatan lintas kurikulum. Sebaiknya wawasan multikulturalisme tidak dimasukkan sebagai beban tambahan sebagai mata pelajaran baru dalam kurikulum yang sudah dirasakan amat berat oleh guru dan peserta didik.

Model kurikulum multikultural mengintegrasikan proses pembelajaran nilai, pengetahuan, dan keterampilan hidup dalam

\section{SIMPULAN}

1. Nasionalisme Indonesia ditimbulkan dari persamaan perangai, nasib, dan tujuan untuk mencapai kesejahteraan rakyat sehingga Negara Indonesia yang sarat akan kebhinekaan tersebut dibangun atas dasar kekeluargaan demi tercapainya kemaslahatan rakyat. Konsep persatuan Indonesia dalam Falsafah Bhinneka Tunggal Ika dan Nasionalisme disebut dengan integrative-pluralis yang secara masyarakat yang multikultural. Muatan nilai, pengetahuan, dan keterampilan multikultural ini bisa didesain sesuai tahapan perkembangan anak dan jenjang pendidikan. Muatan-muatan nilai multikultural perlu dirancang dalam suatu strategi proses pembelajaran yang mendorong terjadinya internalisasi nilainilai. Pengetahuan multikultural dimulai dari pengenalan, penghormatan, dan penghargaan terhadap diri sendiri (termasuk institusi yang membentuk seperti keluarga, lingkungan terdekat). Sesuai tahap perkembangan anak dan jenjang pendidikan, pengenalan dan penghormatan atas diri sendiri diperluas dan dikembangkan menjadi pengenalan dan penghargaan terhadap orang lain. Misalnya, pengetahuan tentang berbagai suku, etnis, adat, tradisi, agama, bahasa daerah di satu daerah, di Indonesia, dan di dunia.

Keterampilan untuk hidup di masyarakat yang multikultural termasuk terampil bernegosiasi, mengemukakan dan menghadapi perbedaan, resolusi konflik, cooperative learning, dan problem solving. Keterampilan ini bisa dimasukkan proses pembelajaran anak baik melalui kegiatan akademik maupun non-akademik. Untuk melaksanakan pendidikan multikultural, sejumlah pekerjaan rumah harus digarap mulai dari rancangan integrasi kurikulum, standardisasi buku dan materi, pengembangan materi dan kurikulum, pengembangan profesional dan pelatihan guru, rancangan kegiatan, hingga rancangan monitoring dan evaluasi (Lie, 2007:30).

konstitusional direalisasikan dalam pasal-pasal UUD 1945.

2. Penerapan pendidikan multikultural masih sebatas ikon dan simbol budaya, maka dari itu diperlukan pengembangan model pendidikan multikultural yang sejiwa dengan Pancasila. Model pendidikan multikultural yang tidak bersifat ahistoris dan mampu menghasilkan luaran pendidikan yang 
cerdas dan terampil untuk hidup di masyarakat yang multikultural termasuk terampil bernegosiasi, mengemukakan dan menghadapi perbedaan, resolusi

\section{DAFTAR RUJUKAN}

Darmodihardjo, Darji. 1978. Pancasila: Suatu Orientasi Singkat. Jakarta. Balai Pustaka 1991. Santiaji Pancasila: Suatu Tinjauan Filosofis, Historis dan Yuridis. Surabaya. Usaha Nasional

Daulat R'jat, Mohammad Hatta, Soekarno Ditangkap, edisi no.69, 10 Agustus 1933, tahun III

Darmawan, Josep J (ed.). 2006. Multikulturalisme: Membangun Harmoni Masyarakat Plural, Yogyakarta: Universitas Atmajaya

Fauzi, Achmad. 1983. Pancasila Ditinjau dari Segi Yuridis Konstitusional dan Segi Filosofis. Malang. Lembaga Penerbitan UB

Hanafi. 2018. Hakekat Nilai Persatuan dalam Konteks Indonesia (Sebuah Tinjauan Konstektual Positif Sila Ketiga Pancasila). Jurnal Ilmiah Pendidikan Pancasila dan Kewarganegaraan . (Online), Volume 3, Nomor 1, Halaman 53-63, Juni 2018 (http://journal2. um.ac.id/index.php/jppk/article/ view/6041/3097, diakses pada 20 Februari 2019)

Haryatmoko. 2008. Sekolah, alat reproduksi kesenjangan sosial: Analisis Kriris Pierre Bourdieu. Majalah Basis, Nomor 07-08, Tahun Ke-57, Juli-Agustus

Ikhsan, M. Alifudin. 2017. Nilai-Nilai Cinta Tanah Air dalam PerspektifAl-Qur'an. Jurnal Ilmiah Pendidikan Pancasila dan Kewarganegaraan. (Online), konflik, kerjasama yang baik, dan pemecahan masalah dalam masyarakat. Keterampilan ini dibutuhkan untuk memupuk integrasi bangsa.

Volume 2, Nomor 2, Halaman 108114, Desember 2017 ((http://journal2. um.ac.id/index.php/jppk/article/ view/2570/1587, diakses pada 20 Februari 2019)

Kaelan, 2009. Filsafat Pancasila: Pandangan Hidup Bangsa, Yogyakarta: Paradigma.

Lie, Anita. 2007. Wawasan Multikultural dalam Pendidikan Karakter. Majalah Basis, No. 07-08, Tahun ke -56, JuliAgustus

Lyotard, J. F. 1991. The Postmodern Condition: Report on Knowledge, Geoff Bennington and Brian Massumi, Manchester: Manchester University Press

Mahfud, Choirul, 2008. Pendidikan Multikultural, Yogyakarta: Pustaka Pelajar, cet II.

Soediman K, 1986, Pancasila dan/dalam Undang-Undang Dasar 1945, Bandung: Binacipta

Soekarno. 1945. Lahirnya Pancasila: Kumpulan Pidato BPUPKI

Suparlan, Parsudi. 2002. "Kesetaraan Warga dan Hak Budaya Komunuti dalam Masyarakat Majemuk Indonesia", Jurnal Antropologi Indonesia, 2002, no. 6. hlm. 1-12

Tilaar, H.A.R. 2004. Multikulturalisme, Tantangan Global Masa Depan. Jakarta. Grasindo

Undang-Undang Republik Indonesia Nomor 20 Tahun 2003 Tentang sistem Pendidikan Nasional, Jakarta: Cemerlang, 2003. 